\title{
Predicting ruminal degradability of lucerne and grass forage protein from in vitro solubility with non-specific bacterial protease or pancreatin
}

\author{
Anna M. Antoniewicz and Irena Kosmala \\ Research Institute on Animal Production, \\ Department of Animal Nutrition and Physiology \\ Sarego 2, 31-047 Kraków, Poland
}

(Received 28 July 1995; accepted 6 November 1995)

\begin{abstract}
Samples of lucerne (25) from the primary growth and 2 regrowths and samples of grass (9) from the primary growth were harvested in successive stages of maturity within one vegetation season and were used to test the applicability of protein solubilization during incubation with a non-specific protease from Streptomyces griseus (Sigma type XIV) or porcine pancreatin to predict in sacco ruminal degradability of crude protein (CP) in dried forage. The effective degradability (ED) of protein in the forage, calculated at $\mathrm{k}=0.06 \mathrm{~h}^{-1}$, ranged from 63 to $88 \%$. The conditions for protease XIV activity given by Krishnamoorthy et al. (1983) and Aufrere and Carthailler (1988), at constant enzyme concentration in the incubation medium and short incubation period, were not suitable for predicting variability in in sacco protein degradability of lucerne due to morphological changes or growth type $\left(\mathrm{R}^{2}=0.183, \mathrm{P}=0.03, \mathrm{RSD}=5.94\right)$. The results were better when a constant ratio of enzyme to protein in a sample was maintained ( $4 \mathrm{U}$ of protease per $100 \mathrm{mg}$ of protein) and duration of incubation was extended to $24 \mathrm{~h}\left(\mathrm{R}^{2}=0.713, \mathrm{P}<0.001, \mathrm{RSD}=3.52\right)$. However, the best fit between enzymatic solubility and effective degradability of lucerne protein was obtained using pancreatin (ca. $5 \mathrm{U}$ of trypsin per $0.5 \mathrm{~g}$ of dry forage): $\mathrm{R}^{2}=0.830, \mathrm{P}<0.001, \mathrm{RSD}=2.71$.

Validation of regression equations with samples of grass forage indicated that solubility with pancreatin was superior to the action of protease from $S$. griseus in predicting ruminal degradability of forage determined in situ in cows ( $\mathrm{R}^{2}$ and $\mathrm{RSD}=0.96$ and $1.64 \%$ vs. 0.59 and $5.15 \%$, respectively).

The regression equations between $\mathrm{ED}(\mathrm{Y}, \%)$ and enzymatic solubility of protein $(\mathrm{X}, \%)$ for the combined sets of lucerne and grass samples $(n=34)$ were for pancreatin: $Y=1.18 X-10.97$, $\mathrm{R}^{2}=0.882, \mathrm{P}<0.001, \mathrm{RSD}=2.84$; for protease: $\mathrm{Y}=1.00 \mathrm{X}+2.93, \mathrm{R}^{2}=0.544, \mathrm{P}<0.001$, $\mathrm{RSD}=5.97$.
\end{abstract}

KEY WORDS: lucerne, grass, protein, rumen degradability, bacterial protease, pancreatin, enzymatic solubility 


\section{INTRODUCTION}

Changes in composition occurring in lucerne plants during maturation (increase of fibre and decrease of crude protein content, Andrieu et al., 1989) also induce changes in the extent of herbage protein solubility (Tamminga, 1982) and degradability (Balde et al., 1993). Thus, forages harvested at a wide range of morphological stages (from early vegetative to late generative) present a good model for testing the suitability of laboratory methods to predict ruminal degradability of protein by using linear regression.

Protein degradation has been estimated from measurements of digesta flow in the small intestine and from protein disappearance during incubation of feed in polyester bags suspended in the rumen (Van Straalen and Tamminga, 1990). Both methods require cannulated animals and are not suitable for routine screening of feedstuffs. Therefore, various solubility tests and enzymatic procedures have been developed (Broderick, 1982; Miller, 1982; Lindberg, 1985).

Pichard and Van Soest (1977) proposed using a commercial protease from Streptomyces griseus, which has a broad specificity for cleavage of peptide bonds, to estimate ruminal protein degradation. Poos et al. (1980) reported that in vitro digestion of different feed proteins using a neutral fungal protease was more highly correlated with in vivo ruminal degradation than was in vitro digestion using several other commercial proteases, including that from $S$. griseus. The method based on the use of the latter protease was further developed by Krishnamoorthy et al. (1983), Poos-Floyd et al. (1985), Aufrere and Cartailler (1988) and Aufrere et al. (1991). However, the results of predicting protein degradation were not always satisfactory.

Aufrere et al. (1991) suggested a $1 \mathrm{~h}$ incubation time for routine analysis of concentrate ingredients, and this duration of incubation also gave the best correlation between enzymatic and in vivo degradation in the work of Poos-Floyd et al. (1985). However, our preliminary results (Antoniewicz and Kosmala, unpublished) indicated that during $2 \mathrm{~h}$ incubation, the protease from S. griseus (1 mg of cnzyme per $500 \mathrm{mg}$ of sample) was not able to differentiate grass forage of 18 and $9 \%$ crude protein (early vegetative and late bloom stage, respectively) according to their effective ruminal degradability (81 and $69 \%$ in sacco, 74 and $73 \%$ in vitro, respectively).

The present study conducted with lucerne and grass forage was undertaken to assess the predictive ability of in vitro incubations with the protease from S. griseus as compared to the results obtained by the in sacco procedure or in vitro incubation with pancreatin. 


\section{MATERIAL AND METHODS}

\section{Feed samples}

Lucerne herbage (a monoculture of Medicago sativa) of primary growth and regrowths was cut at successive stages of maturity throughout the whole vegetation season to produce a set of 25 samples covering a fairly wide range of composition and quality. Grass herbage (Dactylis glomerata 0.72 ; Poa pratensis 0.20 ; Festuca pratensis and others 0.08 ) of primary growth was cut from early vegetative to dry stem stage. Fresh herbage samples were dried at $35^{\circ} \mathrm{C}$ and ground to pass a $1 \mathrm{~mm}$ sieve using a Wiley mill.

Dry forage was analyzed in sacco for protein degradability (Antoniewicz et al., 1995). The assay was conducted on cannulated cows, essentially as described by Ørskov et al. (1980). Calculations of effective degradability (ED) were done using models based on McDonald (1981) assuming a small particle outflow rate $\mathrm{k}$ of $0.06 \mathrm{~h}^{-1}$, with no correction for microbial contamination. Lucerne forage was used to make calibrations (regression equations) for predicting ED from enzymatic solubility, and grass samples were used to validate the obtained equations.

\section{Enzymatic methods}

Assay with bacterial protease

Protease from Streptomyces griseus, type XIV (5.1 units/mg, Sigma Chemical Co., St. Louis, Missouri, USA) was used. One unit represents the quantity of enzyme that will hydrolyse casein to produce colour with the Folin-Ciocalteu reagent equivalent to $1 \mathrm{mmol}$ tyrosine $\min ^{-1}$ at $\mathrm{pH} 7.5$ and $37^{\circ} \mathrm{C}$.

Forage samples $(0.5 \mathrm{~g})$ were incubated in duplicate with enzyme in $40 \mathrm{ml}$ of borate-phosphate buffer $\mathrm{pH} 8.0\left(\mathrm{NaH}_{2} \mathrm{PO}_{4} \cdot 2 \mathrm{H}_{2} \mathrm{O} 8.6 \mathrm{~g}\right.$ and $\mathrm{Na}_{2} \mathrm{~B}_{4} \mathrm{O}_{7} \cdot 10 \mathrm{H}_{2} \mathrm{O}$ $13,17 \mathrm{~g} \mathrm{l}^{-1}$ ). The amount of enzyme was either constant, i.e. 4 units (procedure I) or equivalent to protein content in the incubated sample, $4 \mathrm{U}$ per $100 \mathrm{mg}$ of protein (procedure II and III). Samples were incubated for $2 \mathrm{~h}$ (procedure I and II) or $24 \mathrm{~h}$ (procedure III) by shaking in a water bath at $39^{\circ} \mathrm{C}$. Next, they were filtered through polyester fibre ( $40 \mu \mathrm{m}$ square pore size) and the solid residues were thoroughly washed with distilled water. Feed residues on the filters were deep frozen and in this form quantitatively transferred to Kjeldahl flasks for total $\mathrm{N}$ determination.

\section{Assay with pancreatin}

The enzyme used was porcine pancreatin (Polfa, Warszawa, Poland, $59 \mathrm{U}$ of trypsin $\left.\mathrm{g}^{-1}\right)$, a solution of $2 \mathrm{~g} \mathrm{l}^{-1} 0.1 \mathrm{M}$ phosphate buffer $\mathrm{pH} 7.4(80 \mathrm{ml}$ 
$0.2 \mathrm{M} \mathrm{NaH}_{2} \mathrm{PO}_{4}+420 \mathrm{ml} 0.2 \mathrm{M} \mathrm{Na}_{2} \mathrm{HPO}_{4}$ made up to 1 I with distilled water). Samples $(0.5 \mathrm{~g})$ were incubated with $40 \mathrm{ml}$ of enzyme solution for $24 \mathrm{~h}$ at $39^{\circ} \mathrm{C}$ and further treated the same way as in the procedure with the protease from S. griseus.

\section{Chemical and statistical analysis}

Nitrogen was determined by the Kjeldahl method using Kjeltec Auto 1030 (Tecator, Hoganas, Sweden). The results of in vitro assays were compared to the ED of protein using linear regression and the analysis of variance. Nonaccountable residual mean square variance was expressed as residual standard deviation (RSD).

\section{RESULTS}

Protein solubility of lucerne forage by the $S$. griseus protease depended strongly on the conditions of incubation. The relationship against ED values was poorest at a constant enzyme concentration and $2 \mathrm{~h}$ incubation time (procedure I, Table 1, Figure 1). It improved when the enzyme concentration was equivalent to protein content in forage: slightly at $2 \mathrm{~h}$ incubation (procedure $\mathrm{II}$ ) and significantly when incubation was prolonged to $24 \mathrm{~h}$ (procedure III). As was expected, the closest relationship between ED values and enzymatic solubility was obtained using pancreatin (Table 1, Figure 2). Solubility with pancreatin allowed to account for $83 \%$ of variability in ED values due to maturity and growth type of lucerne forage, while the accountable variance at the best procedure (III) for protease XIV was $71 \%$. There was a very close correlation between the protein solubility results obtained using pancreatin $(Y, \%)$ and the protease from $S$. griseus according to procedure III $(\mathrm{X}, \%)$ : $\mathrm{Y}=0.83 \mathrm{X}+14.27$; $\mathrm{n}=25, \mathrm{R}^{2}=0.92, \mathrm{P}<0.001, \mathrm{RSD}=1.60$.

The results of predicting protein ED values of primary growth of grass using the equations obtained for lucerne (Table 1) and protease (according to procedure III) or pancreatin are shown in Figure 3. The regression statistics are shown in Table 1. The correlation coefficients and RSD were much better for pancreatin. Accountable variance in the prediction of ED values reached $96 \%$ but only $59 \%$ when the equations for pancreatin and protease, respectively, were applied. 


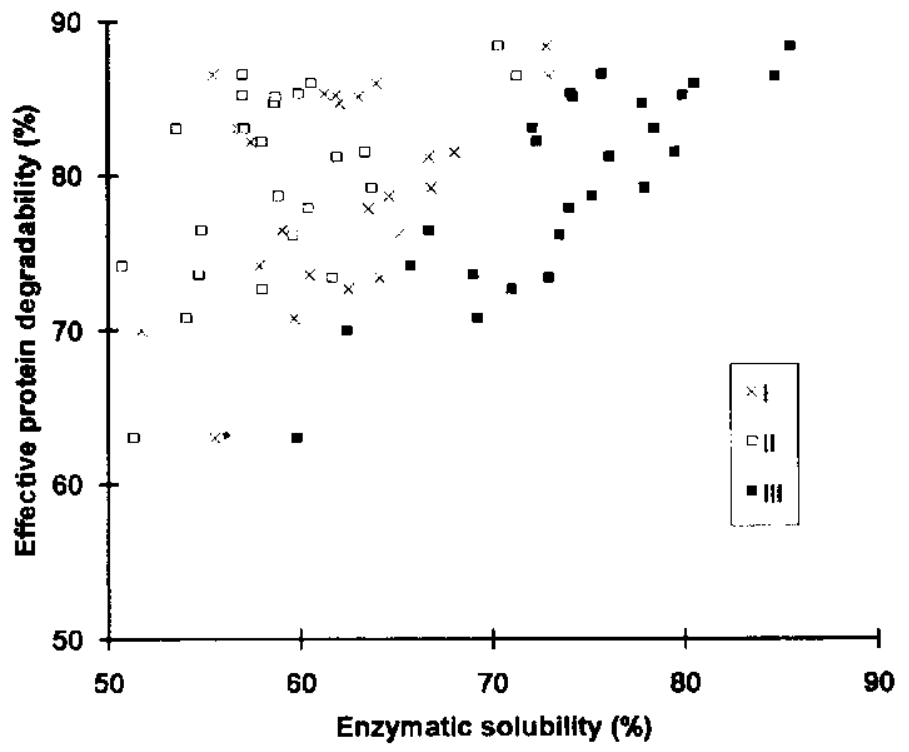

Figure 1. The relationship between ruminal effective degradability of protein of dried lucerne forage and protein solubility under action of protease from Streptomyces griseus:

I 4 units, $2 \mathrm{~h}$

II 4 units per $100 \mathrm{mg}$ of protein, $2 \mathrm{~h}$

III 4 units per $100 \mathrm{mg}$ of protein, $24 \mathrm{~h}$

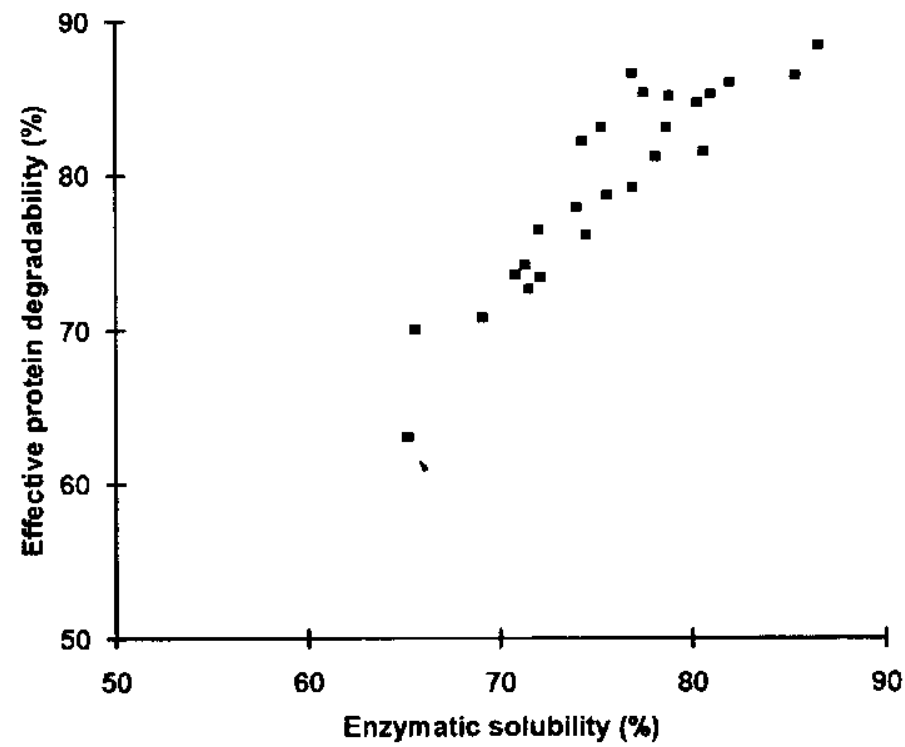

Figure 2. The relationship between ruminal effective degradability of protein of dried luccrnc foragc and protcin solubility under action of pancreatin 
TABLE 1

Statistical parameters of linear regression between enzymatic solubility $(\mathrm{X}, \%)$ and in sacco effective degradability $(\mathrm{Y}, \%)\left(\mathrm{k}=0,06 \mathrm{~h}^{-1}\right)$ of protein of dried lucerne forage $(\mathrm{n}=25$, model $\mathrm{Y}=\mathrm{a}+\mathrm{bX})$

\begin{tabular}{|c|c|c|c|c|c|}
\hline & $\mathrm{R}^{2}$ & RSD & $\mathrm{a}$ & b & Significance of $b$ \\
\hline \multicolumn{6}{|c|}{ Calibration equations (lucerne forage) } \\
\hline Pancreatin $^{1}$ & 0.830 & 2.71 & -2.43 & 1.08 & $\mathrm{P}<0.001$ \\
\hline \multicolumn{6}{|c|}{ Protase from $S$. griseus } \\
\hline I & 0.184 & 5.94 & 46.44 & 0.53 & $\mathrm{P}=0.032$ \\
\hline II & 0.363 & 5.25 & 37.36 & 0.72 & $\mathrm{P}=0.001$ \\
\hline III & 0.713 & 3.52 & 15.07 & 0.87 & $\mathrm{P}<0.001$ \\
\hline \multicolumn{6}{|c|}{ Validation equations (grass forage) } \\
\hline Pancreatin & 0.958 & 1.64 & -1.08 & 0.96 & $\mathrm{P}<0.001$ \\
\hline \multicolumn{6}{|c|}{ Protease from $S$. griseus } \\
\hline
\end{tabular}

${ }^{1}$ conditions of reaction (amount of enzyme per $0.5 \mathrm{~g}$ sample, time of incubation) pancreatin 4.7 units of trypsin, $24 \mathrm{~h}$ protease from $S$. griseus:

I 4 units, $2 \mathrm{~h}$

II 4 units per $100 \mathrm{mg}$ of protein, $2 \mathrm{~h}$

III 4 units per $100 \mathrm{mg}$ of protein, $24 \mathrm{~h}$

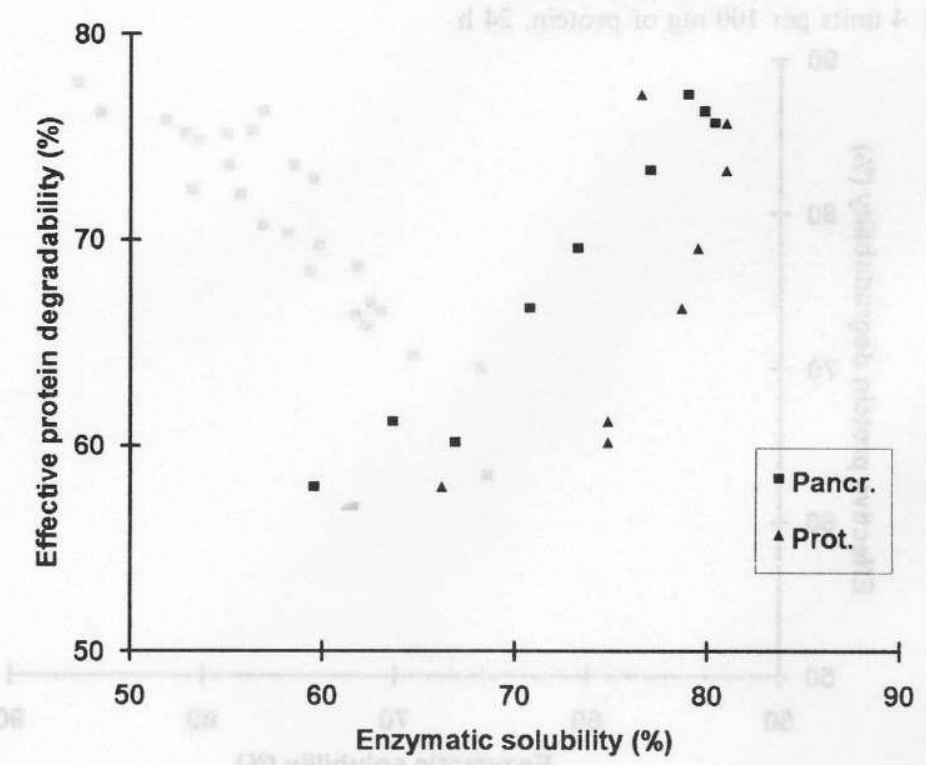

Figure 3. Prediction of the effective degradability of protein of dried grass forage using equations obtained for lucerne forage (Pancr. - pancreatin, Prot. - protease from S. griseus acc. to procedure III, compare Table 1). 


\section{DISCUSSION}

The protease from S. griseus shows a higher rate of protein solubilization than is observed during in sacco incubation in the rumen, especially at a substrate-saturating enzyme concentration (Krishnamoorthy et al., 1983). This could explain the higher protein solubility than degradability from more mature forages of lower protein content when procedure I was used. The low correlation observed in this situation indicated that the enzyme to substrate (feed protein) ratio is of crucial importance. When the ratio is high, the reaction follows first-order kinetics and the rate depends strongly on substrate concentration. On the other hand, when substrate concentration is higher and the ratio of enzyme to substrate lower, the reaction follows zero-order kinetics, the rate of proteolysis is almost constant and not affected by substrate concentration. It is not quite clear which reaction order best describes proteolysis in the rumen. However, there is much to support the suggestion that the reaction deviates from first-order due to limiting enzyme activity (Van Soest et al., 1982). The experiments by Broderick (1978) support first-order kinetics, while those of Nugent and Mangan (1981) show that they could be zero-order. Our results indicate that excess enzyme should be avoided, and the results of in vitro solubilization correlate better with in situ measurements at a constant enzyme to substrate ratio. As protein solubilization under these conditions is less rapid, it was reasonable to increase the reaction time to $24 \mathrm{~h}$.

The better correlation with in situ degradability found when lucerne protein was solubilized with pancreatin than with bacterial protease apparently seems unjustified. However, Craig and Broderick (1980) reported disproportionate release of lysine and, especially, arginine during in vitro degradation by mixed rumen microorganisms. Also artificial trypsin substrates inhibited in vitro degradation of casein by rumen organisms (Craig, unpublished, after Broderick, 1982). These data suggest that initial cleavage by trypsin-like proteases of rumen microbes may limit ruminal protein degradation. Production by microorganisms of trypsin-like proteases may be a good explanation of the satisfactory prediction of ED using porcine pancreatin. Solubility with this enzyme accounted for $83 \%$ of variance in the protein degradability results. Poorer results obtained with the protease from $S$. griseus can be a consequence of a very broad specificity of this enzyme that may obscure differences among feed protein in their susceptibility to microbial proteolysis in the rumen. Another reason may be a difference in the $\mathrm{pH}$ of the solution (7.4 for pancreatin and 8.0 for protease). It seems important to measure in vitro protein degradability under conditions similar to those in the rumen, because the $\mathrm{pH}$ affects solubility of different types of protein in feeds (Krishnamoorthy et al., 1983). However, it is worth noting that the values of 
standard errors of estimate obtained in our study with $S$. griseus protease (Table 1) were much lower than those obtained by Assoumani et al. (1992) (8.1-16.5\%).

With the use of $S$. griseus protease (according to procedure III), and also pancreatin, forages can be evaluated on a relative basis and protein solubilization results are in a reasonable agreement with those obtained by the nylon bag technique for ED estimation. The equation obtained for lucerne and applied to grass fits well in the case of pancreatin and relatively worse as far as protease is concerned.

It may be concluded that measuring solubility by protease from $S$. griseus at a constant enzyme to protein ratio or by porcine pancreatin provides a fairly accurate approach to predicting effective degradability of lucerne protein in the rumen. The equation obtained with pancreatin is more universal and may also be used satisfactorily for grass forage. This indicates that the extent of proteolysis of dry forage by this enzyme is not species-dependent.

\section{REFERENCES}

Andrieu J., Demarquilly C., Sauvant D., 1989. Tables of feeds used in France. In: R. Jarrige (Editor), Ruminant nutrition. Recommended allowanees and feed tables. John Libbey Eurotext, London, Paris, pp. 213-303

Antoniewicz A.M., Kowalczyk J., Karski J., Górska-Matusiak Z., Nalepka, M., 1995. Rumen degradability of crude protein of dried grass and lucerne forage measured by in sacco incubation and predicted by near infrared spectroscopy. Anim. Feed Sci. Technol. 54, 203-216

Assoumani M.B., Vedeau F., Jacquot L., Sniffen C.J., 1992. Refinement of an enzymatic method for estimating the theoretical degradability of proteins in feedstuffs for ruminants. Anim. Feed Sci. Technol. 39, 357-368

Aufrere J., Cartailler D., 1988. Mise au point d'une mèthode de laboratoire de prèvision de la dégradabilité des protines alimentaires des aliments concentrés dans le rumen. Ann. Zootech. $37,255-270$

Aufrere J., Graviou D., Demarquilly C., Vérite R., Michalet-Doreau B., Chapoutot P., 1991. Predicting in situ degradability of feed proteins in the rumen by two laboratory methods (solubility and enzymatic degradation). Anim.Feed Sci.Technol. 33, 97-116

Balde A.T., Vaandersall J.H., Erdman R.A., Reeves J.B., Glenn B.P., 1993. Effect of stage of maturity of alfalfa and orchardgrass on in situ dry matter and crude protein degradability and amino acid composition. Anim. Feed Sci. Technol. 44, 29-43

Broderick G.A., 1978. In vitro procedures for estimating rates of ruminal protein degradation and proportion of protein escaping the rumen undegraded. J. Nutr. 108, 181-190

Broderick G.A., 1982. Estimation of protein degradation using in situ and in vitro methods. In: F.N. Owens (Editor), Proceedings of an International Symposium on Protein Requirements for Cattle. Oklahoma State University, Stillwater, OK, pp. 72-80

Craig W.M., Broderick G.A., 1980. Amino acid release during in vitro protein degradation. Fed. Proc. 39, 891 (Abstr.) 
Krishnamoorthy U., Sniffen C.J., Stern M.D. Van Soest P.J., 1983. Evaluation of a mathematical model of rumen digestion and in vitro simulation of rumen proteolysis to estimate rumen undegraded nitrogen content of feedstuffs. Brit. J. Nutr. 50 555-568

Lindberg J.E., 1985. Estimation of rumen degradability of feed proteins with the in sacco technique and various in vitro methods. Actu Agric. Scand., Suppl. 25, 64-97

McDonald I., 1981. A revised model for the estimation of protein degradability in the rumen. $\mathbf{J}$. Agric. Sci., Camb. 96, 251-252

Miller E.L., 1982. Methods assessing proteins for ruminants, including laboratory methods. In: E.L. Miller, I.H. Pike, A.J.H. van Es (Editors), Protein contribution of feedstuffs for ruminants: application to feed formulation. Butterworth Scientific, London, pp. 18-35

Nocek J.E., 1988. In situ and other methods to estimate ruminal protcin and cncrgy digestibility: A review. J. Dairy Sci. 71, 2051-2069

Nugent J.H.A., Mangan J.L., 1981. Characteristics of the rumen proteolysis of fraction I (18S) leaf protein from lucerne (Medicago sativa L.). Brit. J. Nutr. 46, 39-58

Ørskov E.R., Hovell F.D.DeB., Mould F., 1980. The use of the nylon bag technique for the evaluation of feedstuffs. Trop. Anim. Prod. 5, 195-213

Pichard G., Van Socst P.J., 1977. Protcin solubility of ruminant feeds. Proceedings of Cornell Nutrition Conference, pp. 91-99

Poos-Floyd M., Klopfenstein T., Britton R.A., 1985. Evaluation of laboratory techniques for predicting ruminal protein degradation. J. Dairy Sci. 68, 829-839

Poos-Floyd M., Klopfenstein T., Britton R.A., Olson D.G., 1980. A comparison of laboratory techniques to predict ruminal degradation of protein supplements. J. Anim. Sci. 51, Suppl.1, 389 (Abstr.)

Tamminga S. 1982. Protein metabolism in ruminants with special reference to forage protein utilization. In: T.W. Griffiths, M.F. Maguire (Editors), Forage protein conservation and utilization. Commission of the European Communities, pp. 83-97

Van Soest P.J., Sniffen C.J., Mertens D.R., Fox D.G., Robinson P.H., Krishnamoorthy U., 1982. A net protein system for cattle: The rumen submodels for nitrogen. In: F.N. Owens (Editor), Proceedings of an International Symposium on Protein Requirements for Cattle. Oklahoma State University, Stillwater, OK, pp. 265-279

Van Straalen W.M., Tamminga S., 1990. Protein degradation of ruminant dicts. In: J.Wiscman, D.J.A. Cole (Editors), Feedstuff Evaluation. Butterworths, London, pp. 55-72

\section{STRESZCZENIE}

Szacowanie degradacji żwaczowej hialka zielonki z lucerny i traw na podstawie rozpuszczalności in vitro pod dzialaniem nieswoistej proteazy bakteryjnej lub pankreatyny

Próbki zielonki z lucerny (25) z trzech pokosów i z traw (10) z dwóch pokosów pobierano w miarę postępujących stadiów dojrzałości w jednym sezonie wegetacyjnym i użyto do określenia przydatno. ści oceny rozpuszczalności białka przy inkubacji z nieswoistą proteazą z Streptomyces griseus (Sigma, typ XIV) lub wieprzową pankreatyną do szacowania efektywnej degradacji (ED) białka ogólnego suszonych zielonek. ED białka w zielonkach obliczona dla $\mathrm{k}=0,06 \mathrm{~h}^{-1}$ wynosiła $63-88 \%$.

Warunki działania proteaza XIV podane przez. Krishnamoorthy'ego i in. (1983) i Aufrere i Carthailler (1988) (stale stężenie enzymu w medium inkubacyjnym i krótki czas inkubacji) nie były odpowiednic do rozróżnienia zmienności $w$ degradcji białka lucerny na skutek zmian w stadium 
wegetacji $\left(R^{2}=0,183, P=0,03, R S D=5,94\right)$. Lepsze wyniki uzyskano przy zastosowaniu stałego stosunku enzymu do białka w próbce $i$ wydłużeniu czasu inkubacji do $24 \operatorname{godz}\left(R^{2}=0,713, P<0,001\right.$, $\mathrm{RSD}=3,52$ ).

Najlepszą zgodność między rozpuszczalnością białka lucerny pod działaniem enzymu a wartościami ED uzyskano stosując pankreatynę (ok. 5 jedn. trypsyny na $0,5 \mathrm{~g}$ suchej zielonki): $\mathbf{R}^{2}=0,830$, $\mathrm{P}<0,001, \mathrm{RSD}=2,71$.

Sprawdzenie i potwierdzenie (walidacja) równań regresji przy użyciu prób zielonki $z$ traw pokazało, że rozpuszczalność z pankreatyną pozwalała skuteczniej szacować degradację ocenianą in situ na krowach niż przy działaniu proteazą ze $S$. griseus (odpowiednio $\mathrm{R}^{2}$ i RSD 96 i $0,11 \%$ vs. 59 i $5,15 \%$ ).

Równania regresji do szacowania wartości ED (Y, \%) na podstawie rozpuszczalności enzymatycznej białka ( $\mathrm{X}, \%$ ) opracowane dla połączonego zbioru prób lucerny i traw były następujące: dla pankreatyny $\mathrm{Y}=1,18 \mathrm{X}-10,97, \mathrm{R}^{2}=0,882, \mathrm{P}<0,001, \mathrm{RSD}=2,84$; dla proteazy $Y=1,00 X+2,93, R^{2}=0,544, P<0,001, R S D=5,97$. 